Jurnal Inkofar * Volume 1 No. 1 Juli 2019 * ISSN: 2615-3645 (Print) / 2581-2920 (Online)

Tersedia secara online di: http://www.politeknikmeta.ac.id/meta/ojs/

\title{
SISTEM PENDUKUNG KEPUTUSAN PEMBERIAN KREDIT KENDARAAN RODA DUA MENGGUNAKAN METODE TOPSIS (STUDI KASUS PT. CENTRAL SENTOSA FINANCE CIAMIS)
}

\author{
Hendri Mahmud Nawawi ${ }^{1}$, Herlan Sutisna ${ }^{2}$, Nurul Ichsan ${ }^{3}$ \\ ${ }^{1}$ Teknik Komputer / Fakultas Teknik / STMIK Nusamandiri Jakarta/ mahmudhend94@gmail.com \\ ${ }^{2}$ Sistem Informasi/Fakultas Teknologi Informasi /Universitas Bina Sarana Informaatika/ \\ herlan.her@bsi.ac.id \\ ${ }^{3}$ Sistem Informasi/Fakultas Teknologi Informasi/Universitas Bina Sarana Informatika / \\ nurul.nrc@bsi.ac.id
}

\begin{abstract}
Payments by way of credit or installments are widely used by investors to carry out business in transactions of electronic goods, vehicles and property whose payment nominal is quite large. One company that utilizes this credit service is PT CS Finance, which is a two-wheel finance company. In practice this credit payment often experiences various obstacles, one of which is bad credit. In an effort to reduce the occurrence of bad credit which is the biggest threat for credit service providers companies need a decision before deciding to provide loans to customers or debitors. The principle of credit for 5C Character, Capacity, Condition, Capital and Collateral are factors that must be considered in selecting and sorting prospective debitors. To support the process of giving a decision to give credit by prioritizing $5 C$, the principle of credit with multiple criteria requires a method for deciding the feasibility of accepting or not applying for prospective customers' credit. TOPSIS method as the application of decision making with multiple criteria becomes an alternative method for making decisions from the $5 \mathrm{C}$ principle of credit with the aim of making decisions with the least risk of loss by calculating the criteria weight of each criterion so that the most profitable decisions for the company and prospective customers.
\end{abstract}

Keywords: Vehicle Credit, CS Finance, TOPSIS Method

\begin{abstract}
ABSTRAK
Pembayaran dengan cara kredit atau diangsur banyak dimanfaatkan oleh para pemodal untuk mejalankan usaha pada transaksi barang elektronik, kendaraan dan property yang nominal pembayarannya tergolong besar. Salah satu perusahaan yang memanfaatkan layanan kredit ini adalah PT CS Finance yang merupakan perusahaan pembiayaan roda dua. Dalam praktiknya pembayaran secara kredit ini sering mengalami berbagai kendala salah satunya yaitu kredit macet. Dalam upaya mengurangi terjadinya kredit macet yang menjadi ancaman terbesar bagi perusahaan penyedia layanan kredit dibutuhkan sebuah keputusan sebelum memutuskan untuk memberikan pinjaman kepada nasabah atau debitur. Prinsip kredit 5C Character, Capasitas, Condition, Capital dan Collateral adalah faktor-faktor yang harus diperhatikan dalam memilih dan memilah calon nasabah debitur. Untuk mendukung proses pemberian keputusan memberikan kredit dengan mengutamakan 5C prinsip kredit dengan multiple kriteria dibutuhkan sebuah metode untuk memutuskan kelayakan diterima atau tidaknya pengajuan kredit calon nasabah. Metode TOPSIS sebagai penerapan pengambilan keputusan dengan multiple kriteria menjadi sebuah metode alternatif untuk membuat keputusan dari 5C prinsip kredit dengan tujuan mengambil keputusan dengan resiko kerugian paling minimal dengan menghitung bobot kriteria dari masing-masing nilai kriteria sehingga mengahasilkan keputusan yang paling menguntungkan bagi perusahaan dan calon konsumennya.

Kata Kunci: Kredit Kendaraan, CS Finance, Metode TOPSIS

1. PENDAHULUAN

1.1. Latar Belakang

Populasi kendaraan yang mengikuti populasi penduduk ini dimanfaatkan oleh para lembaga bisnis yang menyediakan jasa atau layanan untuk memberikan kemudahan kepada masyarakat untuk memiliki kendaraan yang diinginkan dengan pembayaran diangsur terutama kredit kendaraan motor.
\end{abstract}


Keinginan masyarakat dan permintaan pasar yang tinggi terhadap kendaraan motor khusunya dimanfaatkan oleh salah satu lembaga pembiayaan kredit kendaraan roda dua untuk memfasilitasi masyarakat yang menginginkan memiliki kendaraan sepeda motor dengan pembayaran diangsur.

CS Finance sebagai pihak developer atau disebut pemberi kredit tidak serta merta memberikan kredit kepemilikan kendaraan roda dua secara praktis dan instan melainkan melalui beberapa tahapantahapan dan syarat-syarat yang harus dipenuhi oleh konsumen pemohon yang disebut debitur. Dengan mengutamakan prinsip 5C Character, Capacity, Capital, Collateral dan Condition pihak CS Finance sebagai pemberi kredit memepertimbangkannya dengan sangat baik dan matang.

Pembayaran dengan cara kredit menjadi alternatif bagi masyarakat yang menginginkan kendaraan secara cepat dengan pembayaran diangsur, selain dengan segera dapat digunakan dan dimanfaatkan, dengan pembayaran secara angsuran dapat meringankan pembayarannya.

Kenyataan dilapangan pembayaran dengan menggunakan lembaga pembiayaan ini sering terjadi beberapa masalah, misalnya keterlambatan pembayaran dari waktu yang telah ditentukan sehingga berdampak kerugian materil kepada pihak perusahaan dan kepada debitur (konsumen) juga tentunya, hal ini sering menyebabkan ketidak harmonisan antara perusahaan dengan konsumen dikarenakan pembayaran yang jatuh dari tanggal yang telah ditentukan membuat perusahaan harus mengambil kendaraan milik konsumen secara paksa apabila konsumen tidak dapat melunasi atau tidak dapat melakukan pembayaran dalam jangka waktu lama tentu saja hal tersebut jelas sangat merugikan konsumen.

Dengan adanya masalah diatas penulis tertarik untuk membuat sebuah program aplikasi dengan memadukan perkembangan teknologi dan aktifitas pembiayaan kredit yang dilakukan oleh pihak perusahaan (CS Finance) dalam sebuah penelitian di salah satu Lembaga Penyedia Layanan Kredit Kendaraan Roda Dua dengan harapan aplikasi ini bisa digunakan untuk melakukan seleksi terhadap beberapa calon debitur (konsumen) yang layak untuk diberikan kredit motor berdasarkan bobot nilai $5 \mathrm{C}$ prinsip kredit.

\section{STUDI PUSTAKA}

\subsection{Sistem Pendukung Keputusan}

Menurut Ita Arfyanti (2012:120) "Sistem penunjang keputusan merupakan salah satu produk perangkat lunak yang dikembangkan secara khusus untuk membantu dalam proses pengambilan keputusan. Sesuai dengan namanya tujuan dari sistem ini adalah sebagai "information sources" atau second opinion yang dapat digunakan sebagai bahan pertimbangan dalam pengambilan keputusan atau kebijakan tertentu, merupakan satu model yang fleksibel yang memungkinkan pribadi-pribadi atau kelompok-kelompok untuk membentuk gagasan-gagasan dan membatasi masalah dengan membuat asumsi mereka sendiri dan menghasilkan pemecahan yang diinginkan".

\subsection{Lembaga Keuangan}

Menurut Dewianty (2012:49) Lembaga Keuangan adalah "setiap perusahaan yang kegiatan usahanya berkaitan dengan bidang keuangan. Kegiatan usaha lembaga keuangan dapat berupa penghimpunan dana dan atau penyaluran dana".

Sedangkan Lembaga Pembiayaan menurut Dewianty (2012:55) adalah "badan usaha diluar bank dan lembaga keuangan non bank yang khusus didirikan untuk melakukan kegiatan yang termasuk dalam bidang usaha lembaga pembiayaan yang mencakup usaha sewa guna usaha, anjak piutang, usaha kartu kredit dan pembiayaan konsumen".

2.3. Kredit

Menurut Sinungan dalam Yohanes (2009:61) "Kredit berasal dari bahasa yunani "credere' yang berarti kepercayaan (trust atau faith). Kepercayaan merupakan dasar utama dalam pemberian kredit bank kepada pihak peminjam)".

Sedangkan pengertian kredit menurut bab 1, pasal 12 Undang-Undang pokok perbankan no. 7 tahun 1992, kredit merupakan penyediaan uang atau tagihan yang dapat disamakan dengan itu, berdasarkan persetujuan pinjam meminjam antara bank dengan pihak lain dalam hal mana pihak peminjam berkewajiban melunasi hutangnya setelah jangka waktu tertentu dengan jumlah bunga yang telah ditentukan.

\subsection{Metode TOPSIS}

Menurut (Siregar, 2017) Mengemukakan bahwa "TOPSIS adalah salah satu metode pengambilan keputusan multikriteria yang pertama kali diperkenalkan oleh Yoon dan Hwang (1981). TOPSIS 
menggunakan prinsip bahwa alternatif yang terpilih harus mempunyai jarak terdekat dari solusi ideal positif dan terjauh dari solusi ideal negatif dari sudut pandang geometris dengan menggunakan jarak Euclidean untuk menentukan kedekatan relatif dari suatu alternatif dengan solusi optimal. Solusi ideal positif didefinisikan sebagai jumlah dari seluruh nilai terbaik yang dapat dicapai untuk setiap atribut, sedangkan solusi negatif-ideal terdiri dari seluruh nilai terburuk yang dicapai untuk setiap atribut. TOPSIS mempertimbangkan keduanya, jarak terhadap solusi ideal positif dan jarak terhadap solusi ideal negatif dengan mengambil kedekatan relatif terhadap solusi ideal positif. Berdasarkan perbandingan terhadap jarak relatifnya, susunan prioritas alternatif bisa dicapai. Metode ini banyak digunakan untuk menyelesaikan pengambilan keputusan secara praktis. Hal ini disebabkan konsepnya sederhana dan mudah dipahami, komputasinya efisien, dan memiliki kemampuan mengukur kinerja relatif dari alternatif-alternatif keputusan."

\subsection{Tahap metode TOPSIS}

Secara umum, prosedur TOPSIS mengikuti langkah-langkah:

1. Membuat matriks keputusan yang ternormalisasi.

Matiks ini berupa tabel-tabel yang telah didapatkan dari hasil inputan pada tabel matriks.

2. Membuat matriks keputusan yang ternormalisasi terbobot.

Matriks keputusan ini memberikan penilaian terhadap inputan tabel matriks dengan mengalikan bobot kriteria terhadap masing-masing kriteria. Normalisasi terbobot ini rumusnya adalah:

$$
\mathrm{rij}=\frac{x i j}{\sqrt{\sum_{i=1}^{m} X i j}} 2
$$

3. Menentukan matriks solusi ideal positif dan matriks solusi ideal negatif.

Solusi ideal positif A+ dan solusi ideal negatif A- dapat ditentukan berdasarkan rating bobot ternormalisasi (yij):

$$
Y i j=W i . r i j
$$

dengan $\mathrm{i}=1,2, \ldots, \mathrm{m} ;$ dan $\mathrm{j}=1,2, \ldots, \mathrm{n}$, sehingga nilai dihasilkan menjadi

$$
\begin{aligned}
& A+=(y 1+, y 2+\cdots y n+ \\
& A-=(y 1-, y 2-\cdots y n-
\end{aligned}
$$

4. Menentukan jarak antara nilai setiap alternatif dengan matriks solusi ideal positif dan matriks solusi ideal negatif.

$$
\begin{aligned}
& D i+=\sum_{i=1}^{n}(y i-y i j)^{2} ; i=1,2, \ldots, m \\
& D i-=\sum_{j=1}^{n}(y i-y i j)^{2} ; i=1,2, \ldots, m
\end{aligned}
$$

5. Menentukan nilai preferensi untuk setiap alternatif. Nilai preferensi ini akan melakukan penjumalah dari seluruh matriks dan menghasilkan nilai keputusan. Rumusnya:

$$
V i=\frac{D i^{-}}{D i^{-}+D i+} ; i=1,2, \ldots m
$$

\section{HASIL DAN PEMBAHASAN}

\subsection{Analisa Kebutuhan}

\subsubsection{Usecase Diagram}

Use Case Diagram dibuat agar pengguna aplikasi dapat memahami proses yang diusulkan dalam pembuatan aplikasi berbasis web. Pada alur usecase diagram menjelaskan langkah-langkah seorang admin database yang melakukan kegiatan setelah login aplikasi. Setelah tampil menu utama admin bias mengolah informasi dan melakukan perhitungan dengan memberikan nilai inputan dari hasil survey dilapangan untuk menilai calon konsumen. 


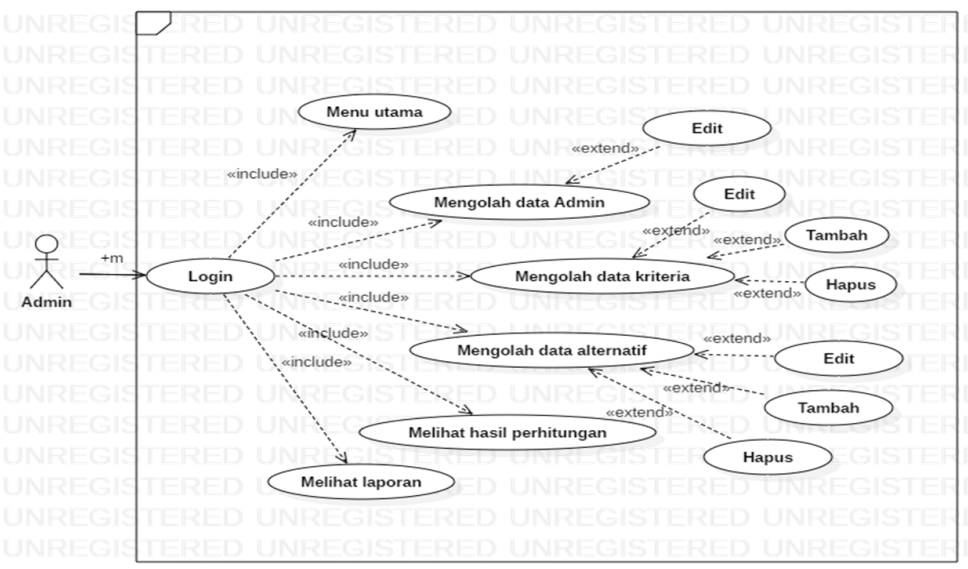

Gambar 1. Usecase Diagram

\subsubsection{Desain Database}

Database dimulai dari transformasi Entity Relationship Diagram (ERD) yang telah dibuat sebelumnya ke Logical Resource Structure (LRS).

1. Entity Relationship Diagram

ERD atau Entity Relationship Diagram merupakan hubungan antar tabel dalam database. Dimana tabel matriks merupakan inputan dari tabel kriteria dan tabel alternatif selanjutnya hasil perhitungan dapat dilihat pada tabel preferensi.

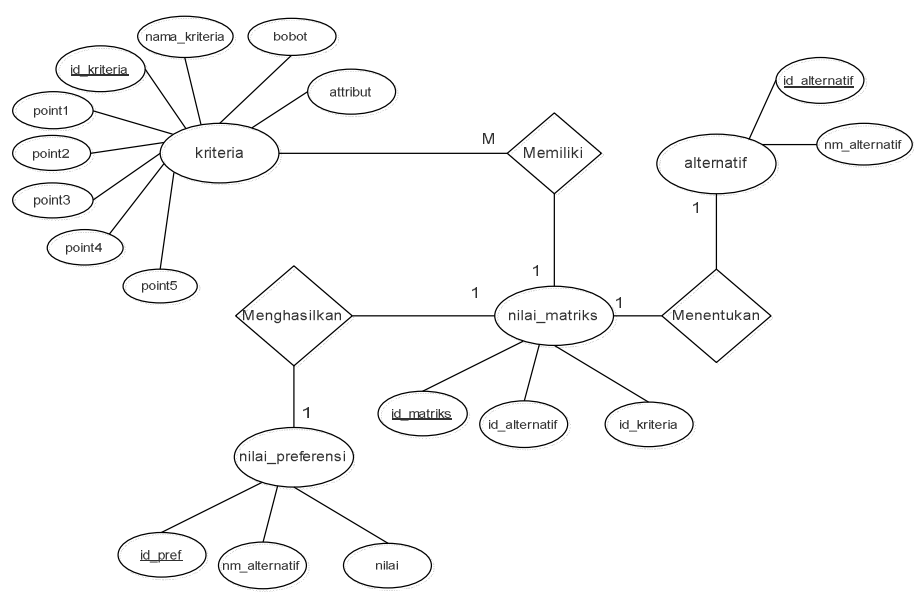

\section{Gambar 2. Entity Relationship Diagram}

2. Logical Relational Structure

Logical Relational Structure (LRS) menjelaskan logika dari tabel tabel yang saling keterkaitan dimana tabel yang saling berkaitan dihubungkan dengan Primary key dan foreign key.

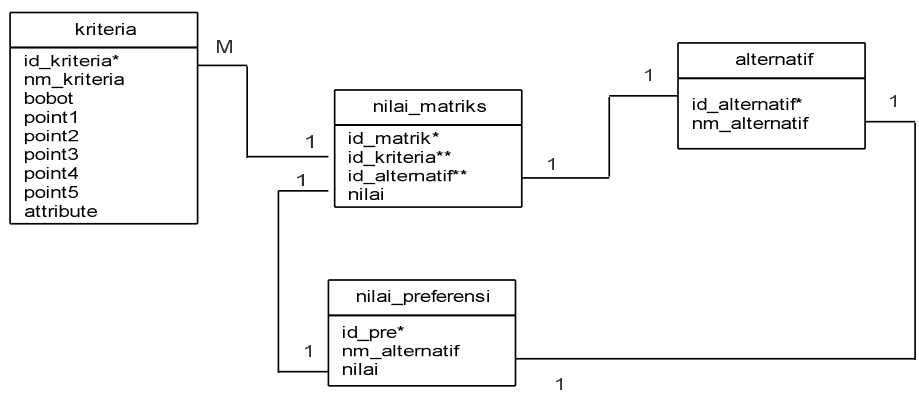

Gambar 3. Logical Relational Structure 


\subsubsection{Pembobotan Nilai TOPSIS}

1. Character. (K1)

Character Ditentukan berdasar-kan hasil penelusuran credit analys terhadap BI cheking yang diperoleh dari data kredit Bank Indonesia. Hasil interview penulis dengan bagian lapangan character ditentukan dengan bobot sebagai berikut:

Tabel 1. Bobot Nilai Character

\begin{tabular}{lc}
\hline \multicolumn{1}{c}{ Keterangan } & Point \\
\hline Pernah melakukan kredit dan angsuran lancar (Bebas BI cheking) & 5 \\
Pernah melakukan kredit dan pernah kena denda & 4 \\
Belum pernah melakukan kredit & 3 \\
Sering kena denda keterlambatan dan atau sedang ada kredit ditempat lain & 2 \\
Pernah kena kredit bermasalah & 1 \\
\hline
\end{tabular}

\section{Capasitas (K2)}

Capasitas ditentukan oleh kesiapan membayarkan angsuran perbulan dengan tenggat waktu yang telah ditentukan. Semakin sedikit masa angsuran yang diajukan maka semakin besar keputusan untuk diberikan pinjaman kredit motor oleh pihak perusahaan. berikut adalah tabel bobot keputusan yang dihitung dalam jumlah bulan masa angsuran.

Tabel 2. Bobot Nilai Capasitas

\begin{tabular}{cc}
\hline Masa angsuran (Bulan) & Point \\
\hline 11 dan 17 & 5 \\
23 dan 29 & 4 \\
35 & 3 \\
$>35$ & 2 \\
\hline
\end{tabular}

\section{Collateral}

Collateral adalah nilai jaminan yang ditentukan yang diambil berdasarkan struk gaji atau surat izin usaha (SIU) bagi wirausahawan, point collateral juga didapatkan dari syarat-syarat adminsitrastif calon nasabah Debitur. Pembobotan point berdasarkan syarat-syarat ini diberikan nilai baik jika syarat-syarat pengajuan sebagai jaminan atau collateral terpenuhi semua.

\section{Tabel 3. Bobot Nilai Collateral}

\begin{tabular}{lc}
\hline \multicolumn{1}{c}{ Syarat-syarat administrasi } & Point \\
\hline Slip Gaji, SIU, KK, KTP, Buku Nikah (Bagi suami-isteri) & 4 \\
SIU, KK, KTP, Buku Nikah (Bagi suami-isteri) & 3 \\
KK, KTP, Buku Nikah (Bagi suami-isteri) & 1 \\
\hline
\end{tabular}

\section{Condition (K4)}

Condition ditentukan oleh credit analys berdasarkan jumlah pendapatan dikurangi beban tanggungan calon nasabah dalam satu bulan. Pembobotan nilai condition ini berdasarkan hasil survey seorang petugas surveyor dilapangan dengan menghitung jumlah pendapatan dikurangi perkiraan beban kebutuhan selama satu bulan. Jika sisa jumlah pemasukan dikurangi jumlah pengeluaran kebutuhan selama satu bulan mendekati atau $>=50 \%$ maka bobot pointnya 5 atau sangat layak, lebih jelasnya disajikan dalam tabel dibawah ini.

Tabel 4. Bobot Nilai Condition

\begin{tabular}{cc}
\hline Sisa Pendapatan Dikurangi Beban & Point \\
\hline $50 \%$ & 5 \\
$40 \%$ & 4 \\
$30 \%$ & 3 \\
$20 \%$ & 2 \\
$10 \%$ & 1 \\
\hline
\end{tabular}


5. Capital (K5)

Capital atau modal ditentukan kesanggupan membayar uang muka sebagai modal awal. Persentasi nilai capital dihitung berdasarkan uang muka terhadap harga kendaraan yang diajukan. Jika Capital dalam hal ini disebutkan uang muka atau Down Payment (DP). Jika konsumen sanggup membayar $20 \%$ uang muka dari harga kendaraan yang diajukan maka bobot point nya 5 atau Sangat Layak. Secara detail pembobotannya bisa dilihat pada tabel dibawah ini.

Tabel 5. Bobot Nilai Capital

\begin{tabular}{cc}
\hline Kesanggupan membayar uang muka/DP & Point \\
\hline $20 \%>$ & 5 \\
$15-19 \%$ & 4 \\
$11-14 \%$ & 3 \\
$6-10 \%$ & 2 \\
$1-5 \%$ & 1 \\
\hline
\end{tabular}

\subsection{Implementasi}

Tahapan dalam melakukan perhitungan dengan menggunakan metode TOPSIS dengan mengikuti langkah-langkah sebagai berikut:

1. Halaman Beranda

Pada halaman ini setelah admin melakukan Login sistem akan menampilkan menu utama, menu utama ini menampilkan beberapa submenu yang bisa dipilih diantaranya menu kriteria, alternative, perhitungan dan logout untuk keluar.

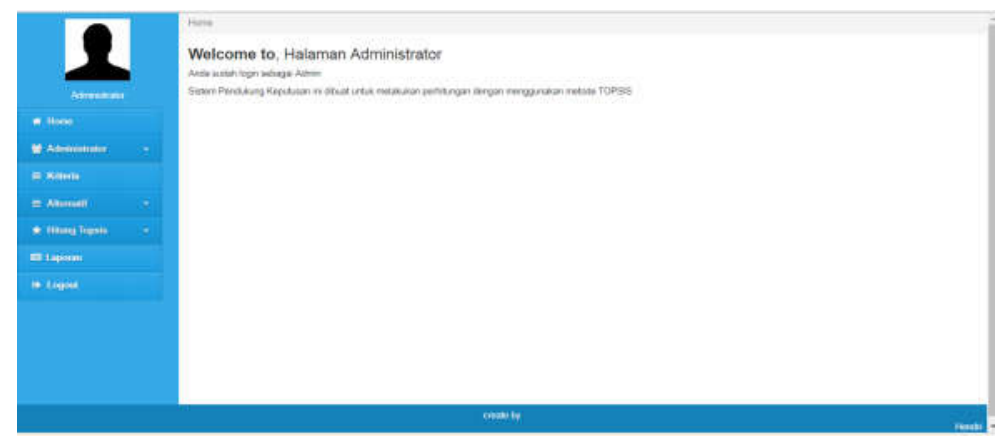

Gambar 4. Halaman Beranda Menu Utama

\section{Halaman Input Nilai}

Pada halaman ini merupakan halaman paling pokok dari penilaian menggunakan metode TOPSIS ini dimana alternarif diisi oleh nama calon debitur yang mengajukan kredit dan 5C prinsip kredit dipilih penilaiannya berdasarkan syarat-syarat pengajuan yang telah di tetapkan sebagaimana pada analisa penilaian bobot TOPSIS. Berikut adalah tampilan halaman penilaian

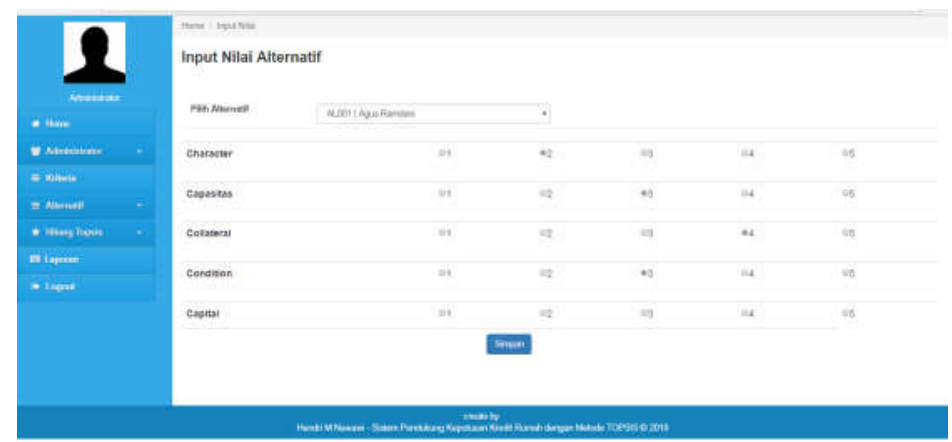

Gambar 5. Halaman Input Nilai 
3. Halaman Perhitungan

Setelah nilai diinputkan untuk menilai alternatif atau pemohon kredit pada halaman ini akan menjumlahkan dan memberikan penilaian terhadap inputan, hasilnya setiap calon pemohon kredit mendapatkan nilai sesuai yang diinputkan pada tabel penilaian. Berikut adalah hasil penilaiannya

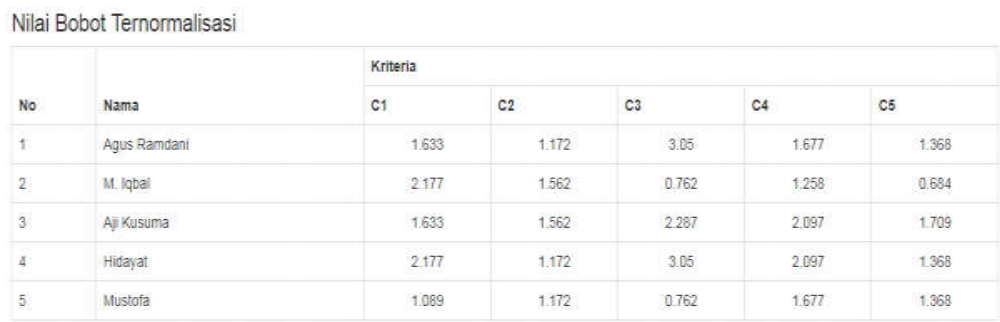

Gambar 6. Halaman Perhitungan

4. Halaman Hasil Nilai Perhitungan

Hasil keputusan dari setiap alternatif (calon nasabah) akan ditampilkan pada nilai preferensi, nilai preferensi ini dibuat keputusan berdasarkan rentang nilai sebagai berikut $0-0,39=$ DITOLAK, 0,40 $-0,59=$ DIPERTIMBANGKAN dan 0,6 - $1=$ DITERIMA

\begin{tabular}{l} 
Nilai Preferensi \\
\begin{tabular}{|l|l|l|}
\hline Nomor & Nama & $\mathrm{V}_{\mathrm{i}}$ \\
\hline 1 & Hidayat & 0.8417 \\
\hline 2 & Agus Ramdani & 0.7427 \\
\hline 3 & Aji Kusuma & 0.6943 \\
\hline 4 & M. Iqbal & 0.3042 \\
\hline 5 & Mustofa & 0.2344 \\
\hline
\end{tabular} \\
\hline
\end{tabular}

Gambar 7. Halaman Nilai Perhitungan

\section{KESIMPULAN DAN SARAN}

\subsection{Kesimpulan}

Dari hasil penelitian dilapangan yang dilakukan oleh penulis terkait studi kelayakan kredit kendaraan motor yang dilakukan di salah satu lembaga pembiayaan kredit kendaraan roda dua (CS Finance) dapat diambil kesimpulan sistem pendukung keputusan ini bisa dijadikan sebagai alternatif untuk menilai kelayakan konsumen yang akan melakukan kredit kepada perusahaan terutama di PT. CS Finance dan Sistem pendukung keputusan dengan metode TOPSIS ini bisa diterapkan diperusahaan, selain simple dan user friendly dengan metode ini kriteria-kriteria yang di butuhkan oleh perusahaan untuk menentukan kelayakan calon nasabah atau debitur bisa di ubah, ditambahkan atau dihapus sesuai kebutuhan.

\subsection{Saran}

Untuk mendukung keberhasilan website sistem pendukung keputusan ini ada beberapa saran yang perlu diterapkan untuk kemajuan dan perbaikan pengembangan website ini supaya dikemudian hari bisa dimanfaatkan secara penuh dan optimal. Adapun saran-saran tersebut diantaranya:

1. Dibuatkannya katalog online untuk memudahkan calon debitur jika ingin melakukan kredit sehingga dengan adanya katalog bisa memberikan informasi harga kendaraan saat ini.

2. Rentannya persaingan antara lembaga pembiayaan satu dengan lainnya website sistem pendukung keputusan ini diperlukan sistem keamanan yang bisa melindungi dari hacker atau cracker.

3. Layanan pengajuan online yang dilakukan oleh konsumen calon debitur misalnya membuat halaman frontend untuk pengajuan konsumen. 


\section{DAFTAR PUSTAKA}

Benning, B.A, I. F. 2015. Sistem Pendukung Keputusan Pembelian Perangkat Komputer Dengan Metode TOPSIS (Studi Kasus: CV. Triad). Jurnal Informatika Mulawarman Vol. 10 No. 2 September $2015,1-7$.

Dewianty, S. 2012. Sistem Lembaga Keuangan Shari'ah. Economic: Jurnal Ekonomi dan Hukum Islam, Vol. 2, No. 1 ISSN: 2088-6365, 41-70.

Ita Afryanti, E. P. 2012. Aplikasi Sistem Pendukung Keputusan Pemberian Kelayakan Kredit Pinjaman Pada Bank Rakyat Indonesia Unit Segiri Samarinda Dengan Metode Fuzzy MADM (Multiple Attribute Decission Making) MENGGUNAKAN SAW (Simple Additive Weighting). Seminar Nasional Teknologi Informasi \& Komunikasi Terapan 2012 (Semantik 2012), 119-124.

Siregar, J. 2017. Sistem Pendukung Keputusan Pemberian KPR (Kredit Pemilikan Rumah) Untuk Nasabah Pemohon Menggunakan Metode TOPSIS (Studi Kasus PT. Bank Central Asia. Tbk). Jurnal Pelita Informatika, Volume 16, Nomor 3, ISSN 2301-9425, 335-342.

Suhari. Y, M. S. 2009. Sistem Pendukung Keputusan Pemberian Kredit Pada Pt. Bpr Artamanunggal Abadi Mranggen. Dinamika Informatika - Vol I No 1, Maret 2009 ISSN : 2085-3343, 59-69.

\section{UCAPAN TERIMAKASIH}

Pada penulisan makalah ini tentunya banyak pihak yang terlibat dalam penyelesaiannya dukungan semangat dan dorongan motivasi yang menjadikan penulis terus berkarya dalam membuat karya ilmiah untuk itu penulis ingin mengucapkan terimakasih yang sedalam-dalamnya terutama kepada Tuhan YME, kedua orang tua tercinta, Bapak Dosen Pembimbing dan kepada semua pihak yang tak bisa disebutkan satu persatu sehingga makalah ini bisa terselesaikan dengan baik. 